$$
\begin{aligned}
& \text { ميان كنش سيستم هيستامينرزيك هيبو كامب پشتى و إيوئيدرزيك سيتوم ميانى بر رفتارهاى شبه- } \\
& \text { اضطرابى إبى }
\end{aligned}
$$

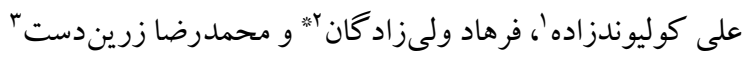

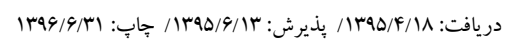

$$
\begin{aligned}
& \text { أخروه علومجانورى، دانشكدة علومزيستى، دانشگاه خوارزمى، تهران، ايران }
\end{aligned}
$$

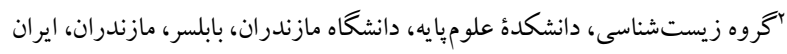

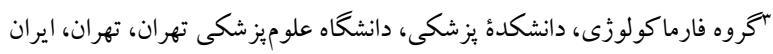

f.valizadegan@umz.ac.ir : مسئول مكاتبات"

جكيده. مهم ترين بخش مغز كه در اضطر اب نقش دارد، سيستم ليمبيك است كه واجد سه بخش مهم هييو كامب، آميگدال و سيتوم است. سيستم سبتوهيبو كامب،

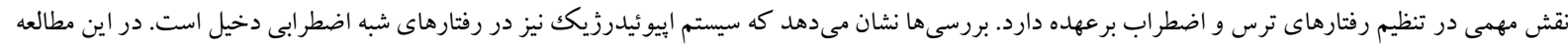

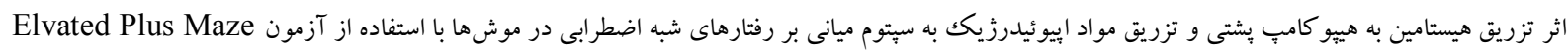

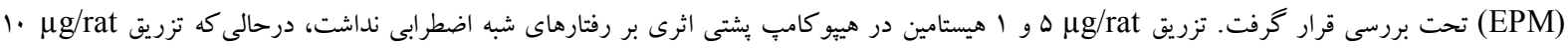

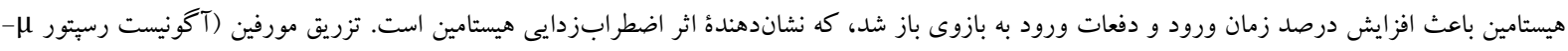

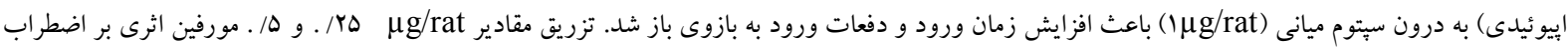

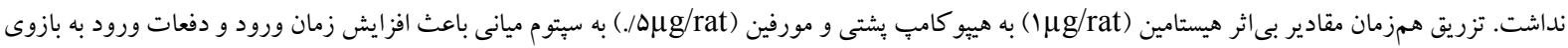

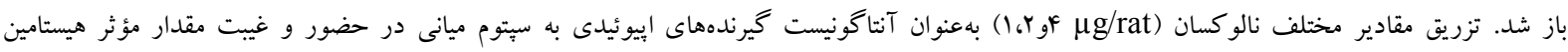

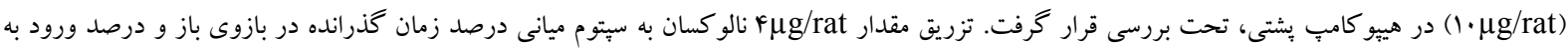

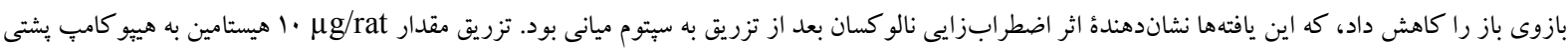
و بهطور همزمان تزريق سه مقدار مختلف نالو كسان (

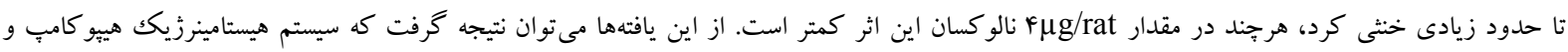

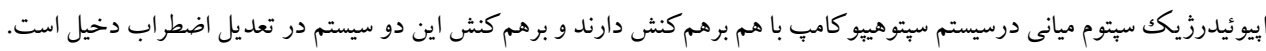

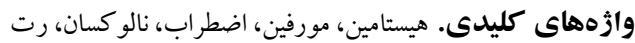

\title{
Interaction between dorso-hippocampal histaminergic and medio-septal opioidergic systems in anxiety behavior
}

\author{
Ali Kolivandzadeh ${ }^{1}$, Farhad Valizadegan ${ }^{2 *} \&$ Mohammad Reza Zarrindast $^{3}$ \\ Received 08.07.2016/ Accepted 03.09.2016/ Published 22.09.2017
}

${ }^{1}$ Department of Animal Biology, Faculty of Biological Sciences, Kharazmi University, Tehran, Iran

${ }^{2}$ Department of Biology, Faculty of Sciences, University of Mazandaran, Babolsar, Iran

${ }^{3}$ Deprtment of Pharmacology, Faculty of Medicine, Medical Sciences University of Tehran, Tehran, Iran

*Correspondent author: f.valizadegan@umz.ac.ir

Abstract. Septohippocampal system plays an important role in regulating fear and anxiety behaviors. In this study, the effects of histamine injected into the dorsal hippocampus and opioidergic agents into medial septum on the anxiety-like behaviors in rats were analyzed, using the Elevated Plus-Maze (EPM) test. Injection of 1 and $5 \mu \mathrm{g} / \mathrm{rat}$ histamine into dorsal hippocampus had no effect on anxiety-like behavior, while injection of $10 \mu \mathrm{g} / \mathrm{rat}$ histamine increased the percentage of open arm time (\%OAT) and open arm entry (\%OAE), which indicated the anxiolytic effects of histamine. Microinjection of morphine, $\mu$-opioid receptor agonist, into the medial septum $(1 \mu \mathrm{g} / \mathrm{rat})$ increased the $(\% \mathrm{OAT})$ and (\%OAE). Doses of $0.25,0.5 \mu \mathrm{g} / \mathrm{rat}$ morphine had no effect on anxiety. Co-administration of histamine ineffective dose $(1 \mu \mathrm{g} / \mathrm{rat})$ to the dorsal hippocampus and ineffective dose of morphine $(0.25 \mu \mathrm{g} / \mathrm{rat})$ to the medial septum increased the $(\% \mathrm{OAT})$ and (\%OAE). Subsequently, injection of different doses of naloxone $(1,2,4 \mu \mathrm{g} / \mathrm{rat})$, as an opioid receptor antagonist, into the medial septum in the presence and absence of an effective dose of histamine (10 $\mu \mathrm{g} / \mathrm{rat})$ in the dorsal hippocampus, was studied. Injection of naloxone ( $4 \mu \mathrm{g} / \mathrm{rat})$ into medial septum decreased the $(\% \mathrm{OAT})$ and $(\% \mathrm{OAE})$, but did not alter the locomotor activity, which indicated the anxiogenic effects of naloxone. Simultaneous injection of histamine $(10 \mu \mathrm{g} / \mathrm{rat})$ into dorsal hippocampus with doses of naloxone $(1,2,4 \mu \mathrm{g} / \mathrm{rat})$ into the medial septum, indicate anxiolytic effects and increased \%OAT and \%OAE in Elevated Plus Maze, although when the dose of naloxone was $4 \mu \mathrm{g} / \mathrm{rat}$, this effect was less observed. The results indicate that hippocampus histaminergic system interact with medial septum opioidergic system and the interaction of these systems modulates anxiety behavior.

Keywords. histamine, morphine, anxiety, naloxan, rat 
هريك از آنها شود، درنهايت، باعث فعاليت نورونهاى

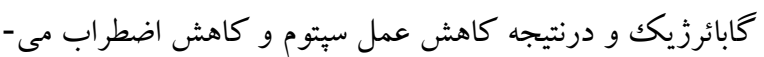
شود (Degroot et al., 2001). تزريق بنزوديازيين ها و ميدازولام

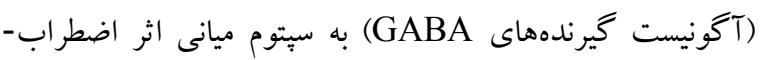

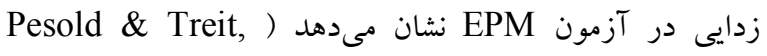
1994). همجنين، تزريق آكونيست كابا A (موسيمول) به اين Drugan \& ( ناحيه باعث ايجاد اثر ضداضطرابى شده است Skolnick, 1986

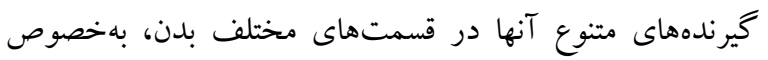

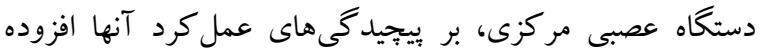
است. مواد مخدر مىتواند سازو كارهاى شكل يذيرى سينايسى را در مدارهاى كليدى مغز ازجمله سيستم دويامينى مزوليمبيك به تصاحب خود در آورد و از اين طريق جنبههاى ويزٔه اعتياد، ازجمله اشتياق به دارو، سيستم يادگيرى، حساسيت رفتارى، حالتهاى مختلف هيجان و باسخ استرسى را تحت تأثير قرار دهند. تجويز

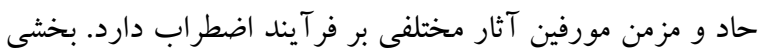

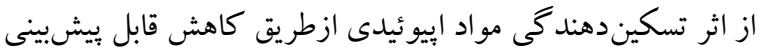
اضطراب است (Bartoletti et al., 1990). تزريق مقدار واحدى إنى از مورفين به داخل صفاق و هستهٔ مر كزى آميكدال موجب افزايش

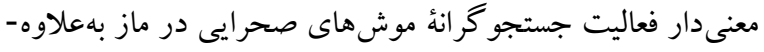

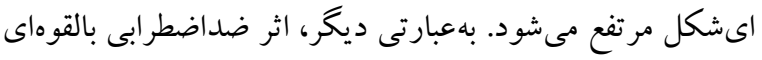
در موش صحر ايى ايجاد مى كند (Koks et al.,1999). اين عمل

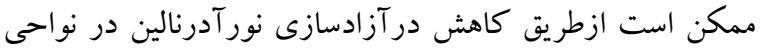
Tanaka et ) متعدد مغزى ازجمله هسته مركزى آميخدال باشد

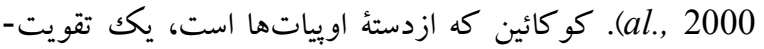
كنندة قوى سيستم پاداشى مغز است كه در انسان اضطراب ايجاد

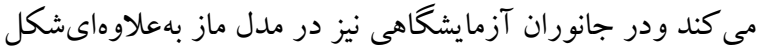
مرتفع رفتار شبهاضطر ابى بهوجود مى آورد و احتمالاً ازطريق تعديل

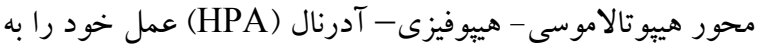
ثمر مىرساند. بنابر اين، مواد مخدر ممكن است زمينهساز بيشتر آثار اضطرابزا درموجود زنده باشد (DeVries et al., 1998).

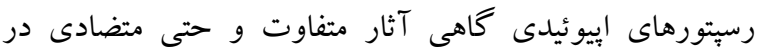
اضطراب دارند؛ براى مثال، در موشهايى كه فاقد رسبتور كايا هستند هيج تغيير فنوتيى در رفتار اضطرابى مشاهده نمى دشود.

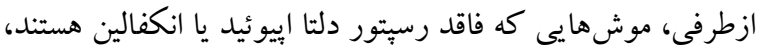

مطالعات الكتروفيزيولوزى و بيوشيميايى وجود سيستم Panula et ) هيستامينرزيك را در اعصاب مركزى اثبات كردهاند

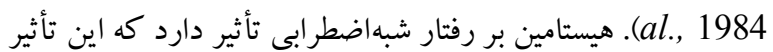
در مطالعات مختلف تاحدودى متفاوت بوده است. تزريق هيستامين در هييو كامٍ يُتى موشها اثر شبهاضطرابزدايى را در آزمون (EPM) Elvaeted Pluse Maze تزريق آن به داخل آميخدال مركزى و هييو كامٍ شكمى موشها Zarrindast et al., ) باعث بروز رفتار شبهاضطرابى مى مونود

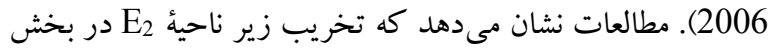

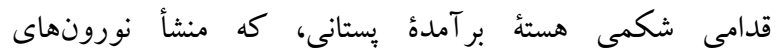
هيستامينرزيك است، باعث كاهش اضطر اب در مدل Plus-Maze مىشود (Frisch et al., 1998). همجنين در برخى مطالعات مشخص شده است فشارهاى عصبى كه باعث القاى اضطر اب مى شوند مىتوانند ميزان رهايش هيستامين از نورونهاى هيستامينرزيك را افزايش دهند (Yamatodani et al., 1985). ناحئ سيتوم مجموعهاى از هستها و دسته هاى فيبرى است كه در ميان شاخهاى قدامى بطنهاى جانبى، زيربخش ميانى و قدامى كوريوس كالوزوم بين دو نيمكره و در قسمت يشتى بخش مئس ميانى

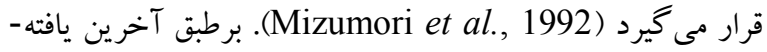

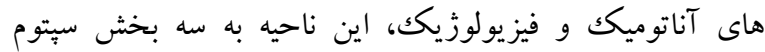
بشتى، سيتوم جانبى و سبتوم ميانى تقسيم مىشود ( Paxinos, 1994). سبتوم جانبى بزرگكترين بخش ناحية سيتال بوده كه

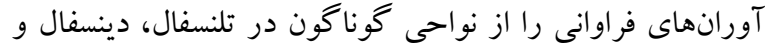
ساقهُ مغز دريافت مى كند (Swanson \& Cowan, 1979).

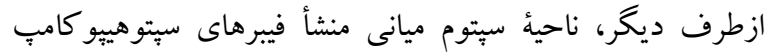
است كه مسيرى مهم براى حافظة كارى محسوب مى مشود (Givens \& Olten, 1990). مطالعات نشان مىدهد كه تخريب لترائ سبتوم باعث كاهش ترس و اضطراب مىشود. ارتباط بين سيتوم و هييو كامب به گونهاى است كه نورونهاى كابائرزيك،، كه از سلولهاى غيرهرمى منشأ مى گيرند، از نورونهاى كولينرزيك عصبدار مىشوند (Amaral, 1995) و نورونهاى كلوتاماترزيك كه از سلولهاى هرمى منشأ مى گيرند نيز با نورونهاى كولينرزيك عصبدار مىشوند كه آنها نيز به نورونهاى كابائرزيكك ختم مىشوند. جنانجه تحريك كولينرزيك باعث فعاليت 
درصورت ايفاى نقش، نوع و نتيجه برهم كنش اين سيستم با سيستم

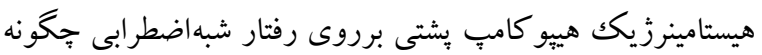

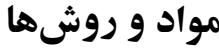 حيوانات مورد آزمايش}

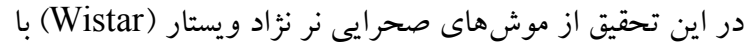

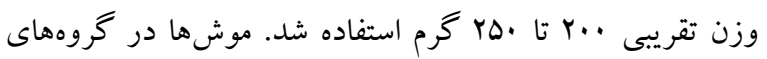

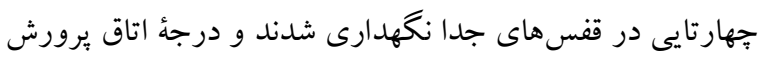

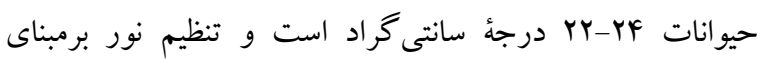

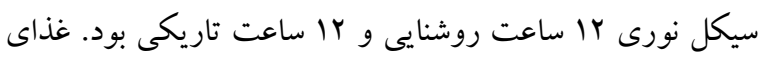
مخصوص موش و آب كافى در تمام مدت نخهدارى بهجز زمان

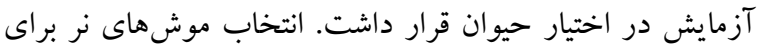

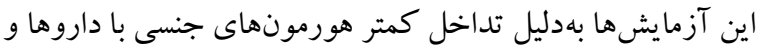

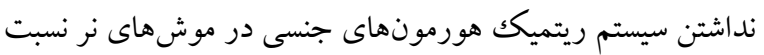
به موش هاى ماده بود.

\section{جر احى استريوتاكسيك و كانول كذارى} اين روش جراحى با استفاده از دستكاه استريوتاكس ولوان و به كمكك

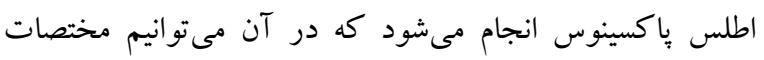
نواحى مختلف مغز موش صحرايى را تعيين كنيم. هر موش ابتدا

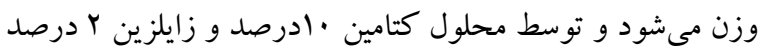

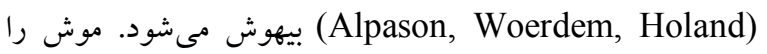
پِ داز بيهوششدن در دستگاه استريوتاكس قرار مىدهيم. اين

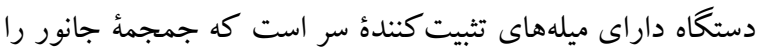

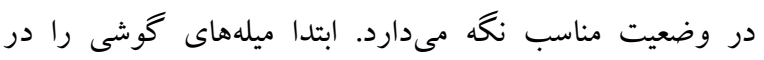

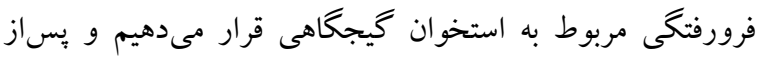

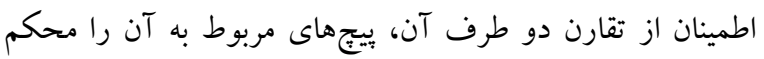
مى كنيم. سبس، يوزهُ حيو ان را در ميلةُ يوزمبند قرار مىدهيم و بيجيج

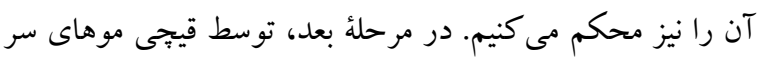

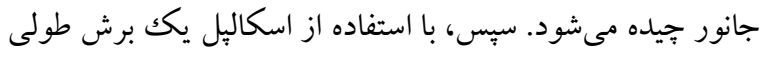
در امتداد شيار سازيتال ميانى جمجمه در يوست سر ايجاد مى شود. محل شكاف ضدعفونى و با استفاده از ينبة استريل آغشته به الكل

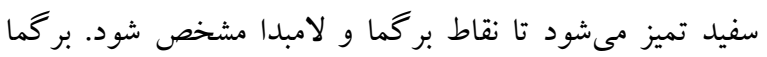

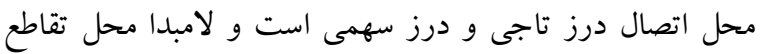

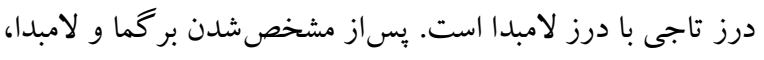

Filliol et al., ) افزايش شاخصهاى اضطرابى را نشان مىدهند

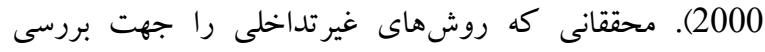

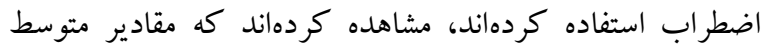
نالوكسان ونالتروكسان (بلوكر رسيتورب) اثر ضداضطراب بنزوديازيين ها را افز ايش مىدهند (Nobre et al., 2000). هييو كامٍ داراى ارتباطات متعددى با قسمتهاى زيادى از قشر مخ، دستكاه ليمبيك يعنى آميگدال، هييو تالاموس، سيتوم و اجسام

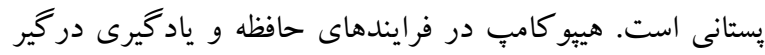

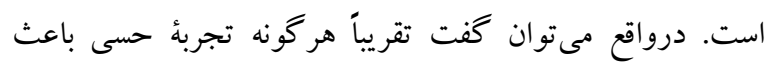

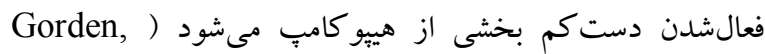

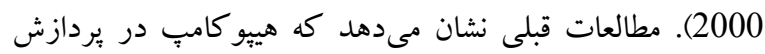

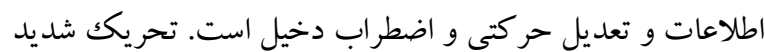
سلولهاى هييو كامب باعث اختلال در برخى اعمال هييو كامب لتب ازجمله بردازش محرك كهاى حسى مىشود. گزارشهايى وجود دارد كه بيان مى كند حالت تحريك بيشازحد طبيعى هييو كامٍ إن در بيمارى اسكيزوفرنى و برخى اختلالات اضطرابى وجود دارد. (Moghaddam et al., 2003)

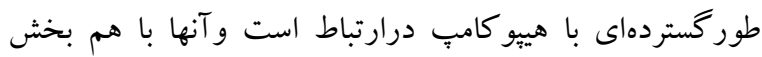
درخورتوجهى از دستگاه ليمبيك را تشكيل مىدهند ( Degroot et al., 2001

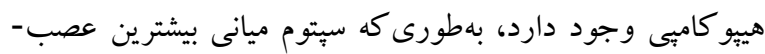
رسانى به هييو كامب را درميان هستهاى زيرقشرى دارد وعصب-

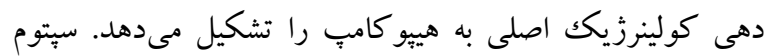
ميانى بهطور مؤثر فعاليت هييو كامبى را تنظيم مى كند ( Mizumori (et al., 1992 استيل كولين ازجمله نوروترانسميترهاى ارتباطى

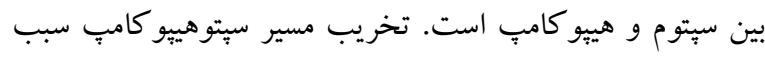

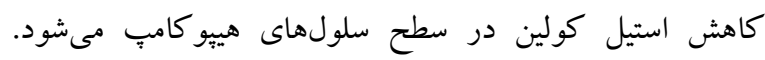

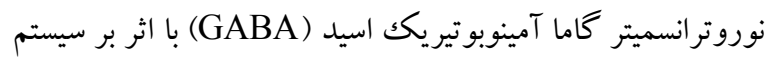
سبتو هييو كامب نقش مهارى القا مى كند. گيرندهاى GABA در

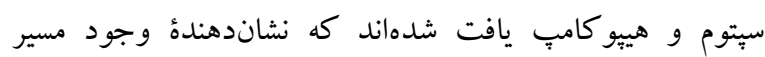
كابائرزيكك در هر دو مسير سبتوم به هييو كامٍ و در داخل خود

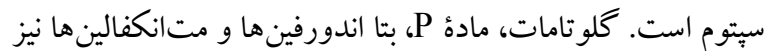

در تعديل اين مسير نقش دارند (Lamour et al., 1989). هدف اين مطالعه بررسى اين موضوع است كه آيا اساساً سيستم

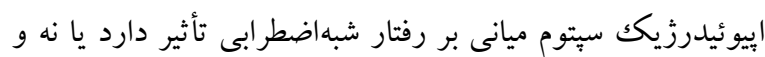


دارد و براى جلو گيرى از افتادن موش صحرايى در دو طرف و

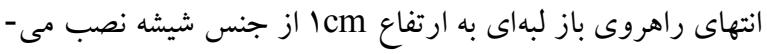

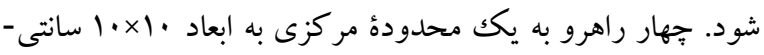

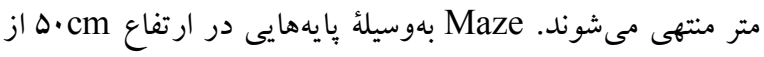

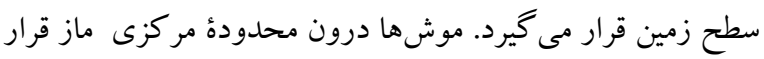

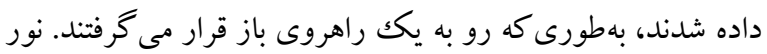

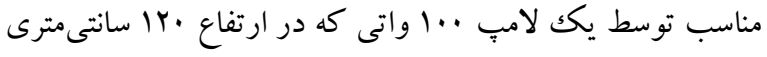

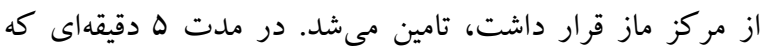

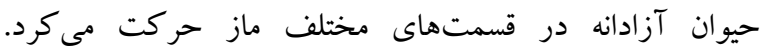

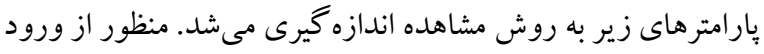

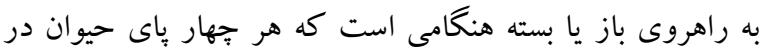

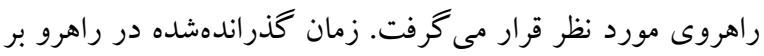

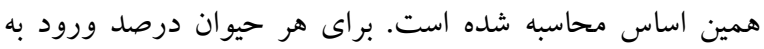
راهروى باز (\%Open Arm Entry: \%OAE) و درصد زمان كذراندهشده در راهروى باز (\%OAT Arm Time : \%OAT)

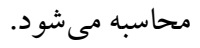

\section{برش بافتى به منظور تعيين موقعيت تزريق}

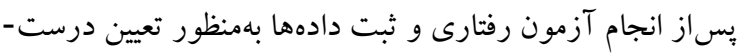
بودن محل تزريق، لازم است مقاطعى از ناحئ مورد نظر تهيه شود

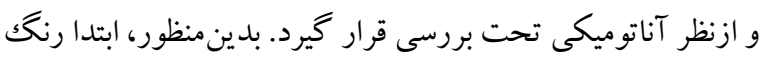
متيلن بلو ادرصد به درون نواحى مورد نظر تزريق مىشود. سبس،

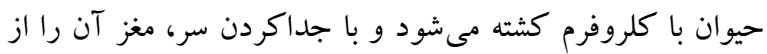

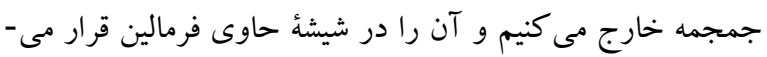

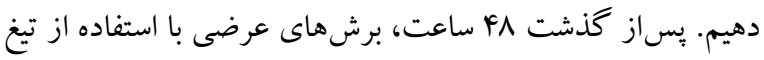

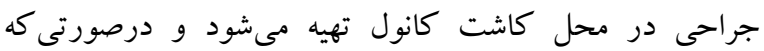

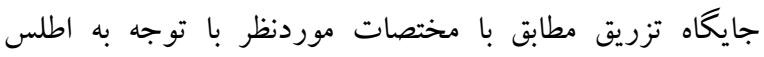
ياكسينوس نباشد، دادههاى مربوط به حيوان از بررسى آمارى حذف مىشود. تحليل آمارى

افزايش زمان حضور در بازوهاى باز و تعداد ورود به بازوهاى باز معيار كاهش اضطراب در نظر گرفته شد. اطلاعات ازطريق تحليل واريانس ANOVA تحت بررسى قرار گرفت. ANOVA يكطرفه براى مقايسة مقادير مختلف هيستامين در هييو كامب و مورفين

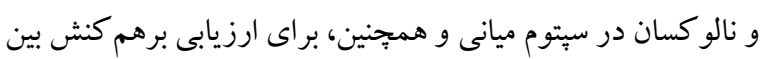

براساس اطلس بِ كسينوس، مختصات محل كانول گذارى در ناحئ

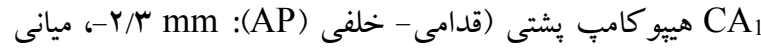
جانبى (ML): (قدامى- خلفى (AP): ML mm) (ML)

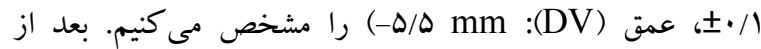
مشخصشدن مختصات دقيق نواحى هيبو كامٍ پشتى و سبتوم ميانى، با استفاده از متههاى كوجكك، جمجمه را در اين نواحى سوراخ مى كنيم. در مرحلة بعد، كانول راهنما (تهيهشده از سر

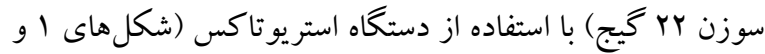
r) در درون سوراخ قرار داده مىشود. به كمك خط كش عمودى دستكاه، مختصات نقطة عمقى را بهدست مى آوريم و به كمك درو خط كش عمودى كانول راهنما را تا عمق مورد نظر فرو مىبريم.

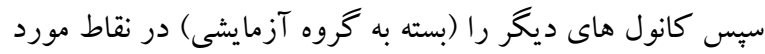
نظر به همين صورت قرار مىدهيم. در مرحله بعد، اطراف كانول يا تانيا

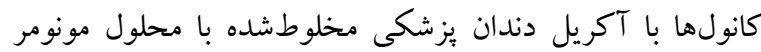

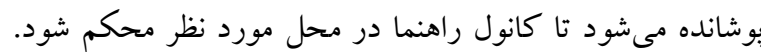

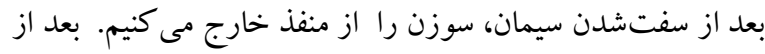
اطمينان از سفتشدن سيمان، حيوان را از دستگكاه خارج مى كنيم. همة حيوانات يككهنته بساز جر احى دوره بهبودى بس از بيهوشى راطى مى كنند. تزريق داخل هيبو كاميى و داخل سيتومى

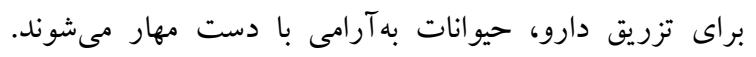

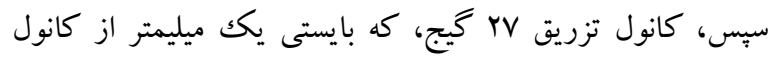

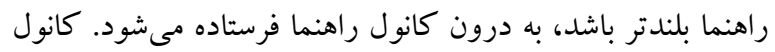

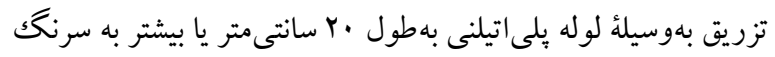

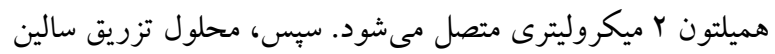
يا دارو به حجم كل

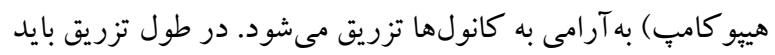
سعى كرد كه فشار عصبى به حيو ان وارد نشود.

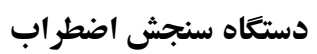
براى سنجش اضطر اب دستكاه Elevated Plus Maze استفاده مىشود. اين ابزار از جنس جوب وإس و داراى جهار بازو به شكل علامت مثبت (+) است. ابعاد راهروى باز و بسته 10 10 50 (-)

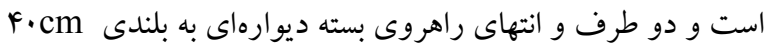




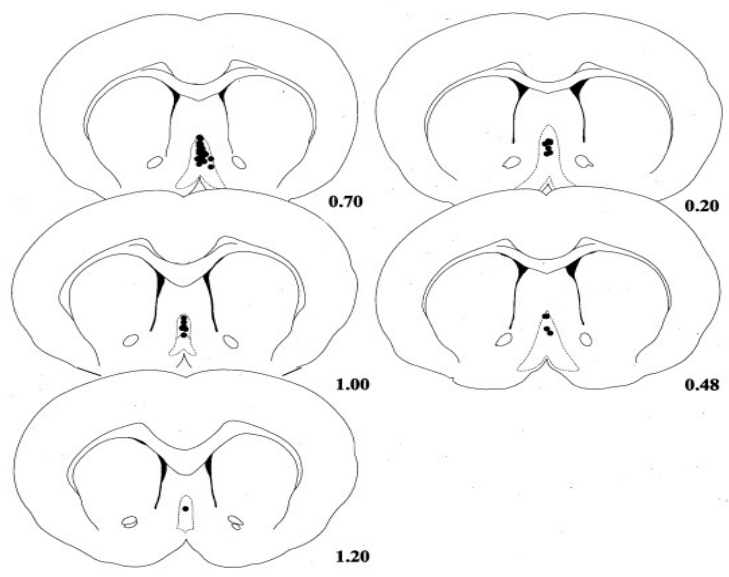

شكل ا- شكلهاى شماتيك از برشهاى كنترل مغز موش نشاندهندة موقعيت نسبى جايگاههاى تزريق در سيتوم ميانى.

Fig. 1. Schematic figures of slices of rat brain indicating the relative positions of injections in medial septum.

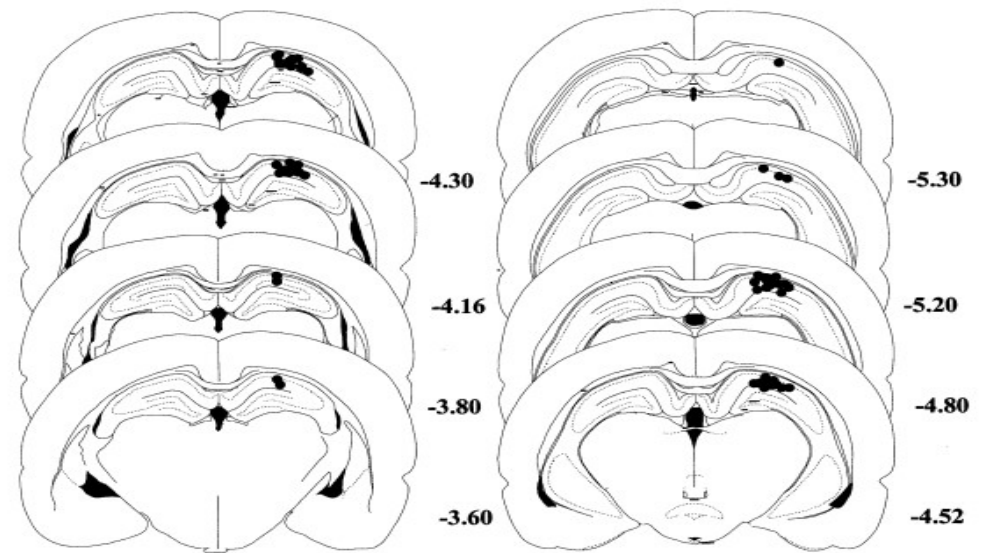

شكل r - شكل شماتيك از برشهاى كنترل مغز موش نشاندهندة موقعيت نسبى جايگاههاى تزريق در هييو كامب پشتى.

Fig. 2. Schematic figures of slices of rat brain indicating the positions of injections sites in dorsal hippocampus.

شكل ب نشاندهنده اثر تزريق مقدارهاى مختلف هيستامين به هيبو كامبٍ بشتى بر رفتارهاى شبهاضطرابى است. مقدارهاى مختلف هيستامين (1, 5, 10 بg/rat) به هيبو كامٍ پِتى تزريق شد. ANOVA يككطرفه نشان داد كه مقدار $10 \mu \mathrm{g} / \mathrm{rat}$ هيستامين باعث تغيير در OOAT \%OAE , [F(3,20)=10.74, $p<0.001]$, شده $[p<0.001$ [F(3.20)= 1.91, است، ولى تغييرى در فعاليت حركتى

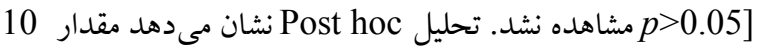
بg/rat هيستامين بهصورت بارزى OAT و OOAE ر ا افزايش مىدهد كه بر اثر اضطرابزدايى هيستامين دلالت دارد.
هيستامين و مورفين مورد استفاده قرار گرفت. ANOVA دو طرفه نيز براى ارزيابى برهم كنش هيستامين و نالو كسان استفاده شد. بهدنبال F-value معنادار، تحليل Post-hoc (آزمون Tukey) براى مقايسٔ كروهها با استفاده از نرمافزار SPSS انجام كرفت. تفاوت با 0.05>pبين گروههاى آزمايشى در هريكك از نقاط بهمنزلهُ آمار Sigma Plot معنى رسم شدند.

\section{نتايج} اثر تزريق درونهي⿻و كاميى هيستامين بر اضطراب 
فعاليت حر كتى [F(3,20)= 2.48, نشان مىدهد كه تزريق اين مقدار نالو كسان به سبتوم

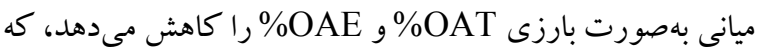
بر اثر اضطراب زايى نالو كسان دلالت دارد.در سمت راست واين نمودار اثر تزريق درونهيبو كامبى هيستامين در مقدار مؤثر 10 Mg/rat

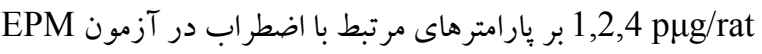

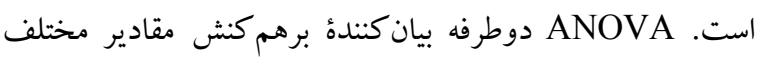

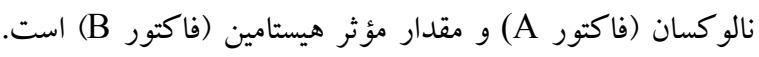

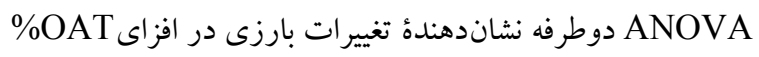

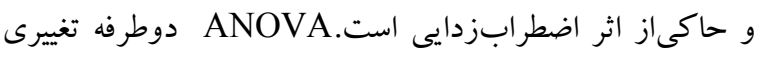
در هارامترهاى OAE\% و فعاليت حر كتى (LOC) نشان نداد. \%OAT: [Factor A: $\mathrm{F}(3,48)=6.86, p<0.01$ ], [Factor B: $\mathrm{F}(1,48)=82.26, \quad p<0.001], \quad[$ Factor $(\mathrm{A} * \mathrm{~B})$ : $\mathrm{F}(3,48)=1.14, p>0.05]$. \%OAE: [Factor A: $\mathrm{F}(3,48)=4.38, p<0.001]$, [Factor B: $\mathrm{F}(1,48)=23.03, p<0.001], \quad[$ Factor $(\mathrm{A} * \mathrm{~B})$ : $\mathrm{F}(3,48)=0.30, p>0.05]$.

LOC: [Factor A: $\mathrm{F}(3,48)=2.64, p>0.05]$, [Factor B: $\mathrm{F}(1,48)=0.10, p>0.05]$, [Factor $(\mathrm{A} * \mathrm{~B}): \mathrm{F}(3,48)=$ $0.67, p>0.05]$.

تحليل Post hoc نشان مىدهد تزريق مقدار ·1 ميكرو گرم

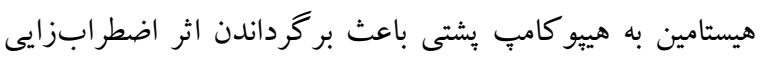
نالو كسان مىشود.

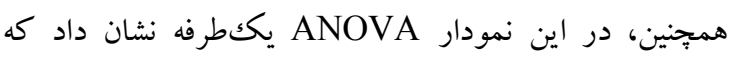

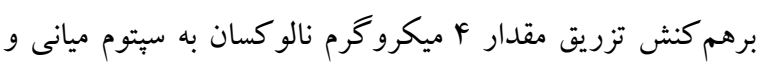

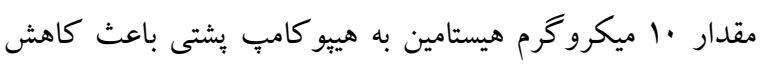
\%OAT كه تغيير معنى دارى در OAE\% و فعاليت حر كتى مشاهده نشده

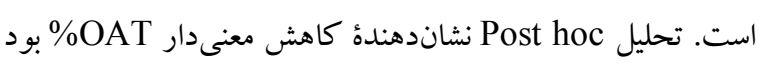
كه حاكىاز اين است كه مقدار مؤثر نالو كسان در سيتوم ميانى اثر

$$
\text { اضطر اب زدايى هيستامين را تعديل كرده است. }
$$

بحث

سيستم سيتوهييو كامب بخشى از سيستم ليمبيك است كه در

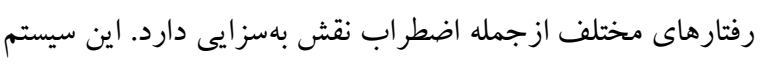

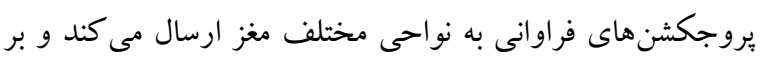

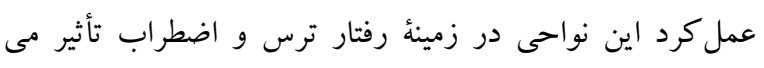

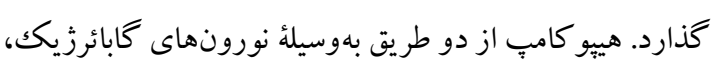

\section{اثر تزريق مورفين به سيتوم ميانى بر اضطراب}

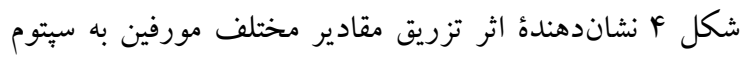
ميانى بر رفتارهاى شبه اضطرابى است. مقادير مختلف مورفين (0.25, 0.5, 1 بg/rat) طرفه نشان مى دهد كه تزريق مقدار \%OAE , در [F(3,20)=5.23, $p<0.01]$ حركتى [F(3,20)=2.21, $p>0.05$ ] ايجاد نمى كند. تحليل

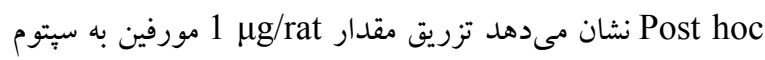

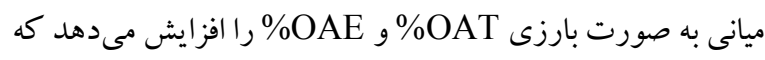
نشان از اثر اضطرابزدايى مورفين در سيتوم ميانى دارد.

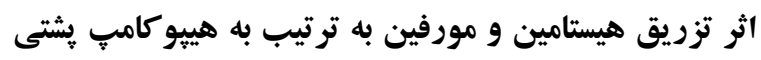

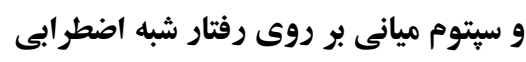
شكل ه نشاندهندة اثر تزريق مقادير بى اثر هيستامين (1 بg/rat)

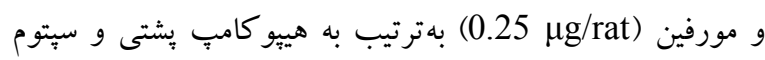

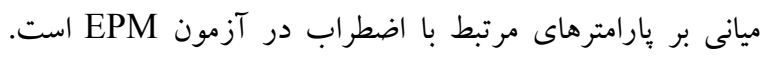

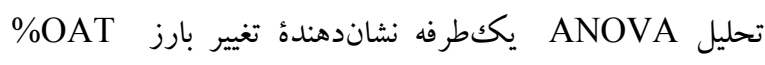
$\%$ OAE $[\mathrm{F}(3,20)=$, [F(3,20) $=45.31, p<0.001]$ ] 39.22. p>0.001 است، درحالى كه هيج تغييرى در فعاليت

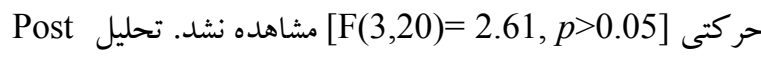

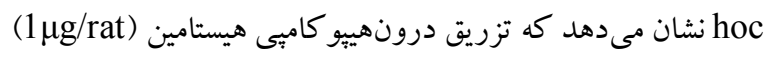

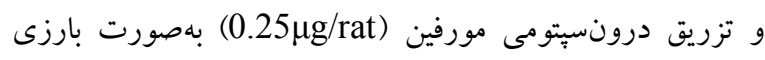
\%OAT و و و ما افزايش مىدهد كه بر اثر سينرزيستى

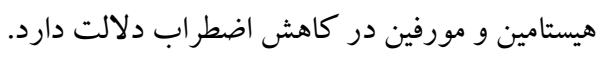

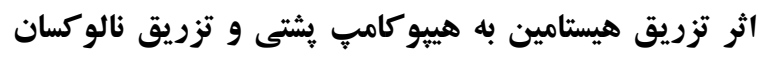

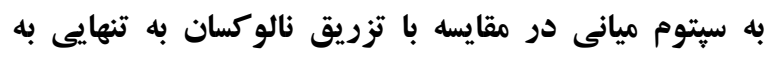
سيتوم ميانى بر رفتار هاى شبه اضطرابى دمانى

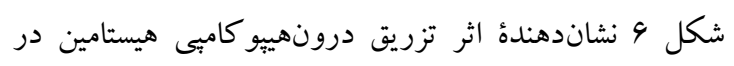

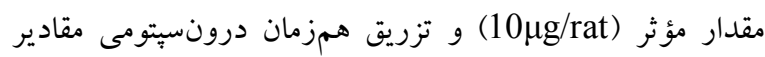

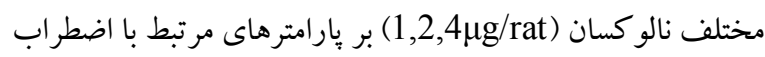
در آزمون EPM است. در سمت جِ اين نمودار هميجنين، اثر تزريق مقادير مختلف نالوكسان به سيتوم ميانى بر اضطراب نيز

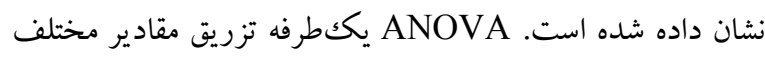
نالو كسان به سبتوم ميانى نشاندهندة كاهش معنىدار $[\mathrm{F}(3,20)=0.06$, 6OAE g [F(3,20)=4.44, $p<0.05]$ [ 

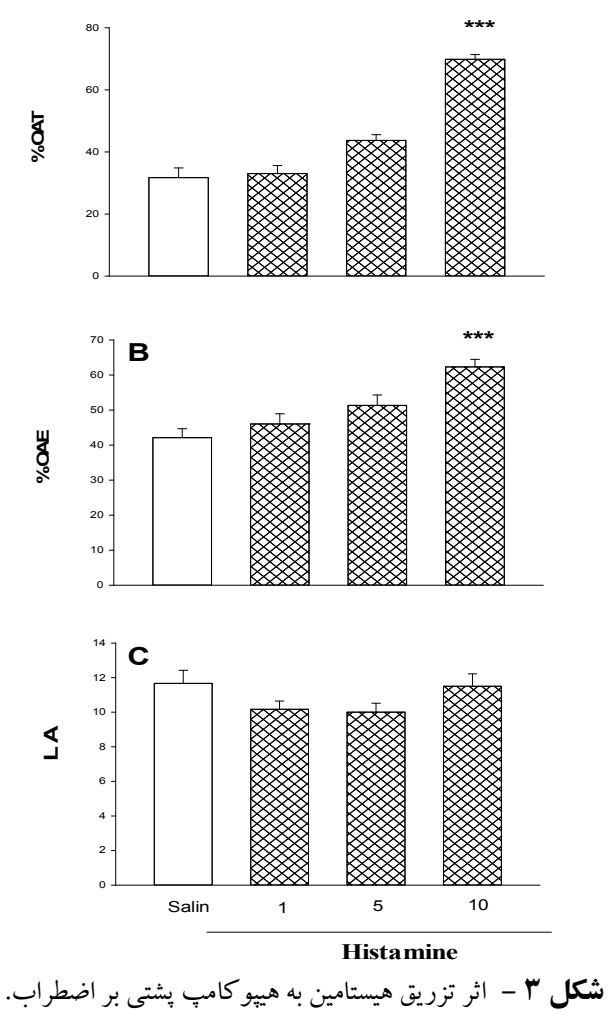

Fig. 3. Effects of histamine microinjection into dorsal hippocampus on anxiety.
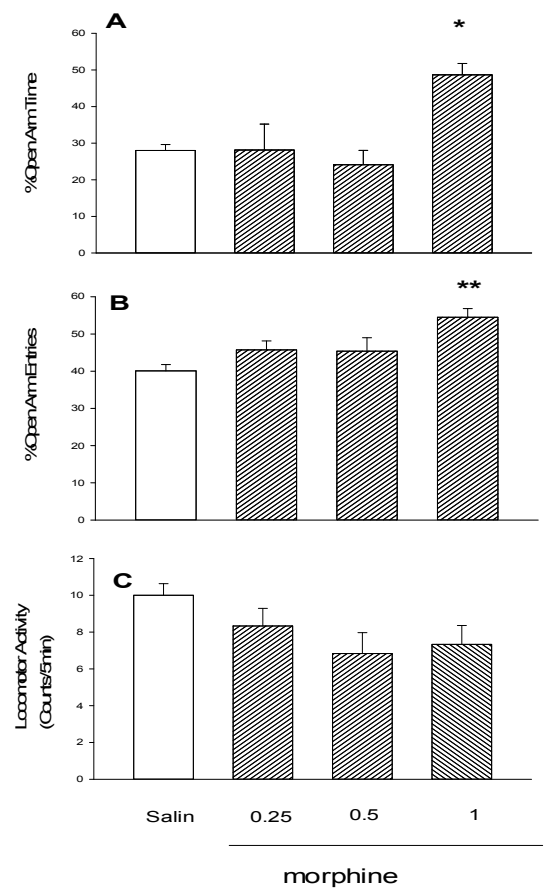

شكل ع- اثر تزريق مورفين به سيتوم ميانى بر اضطراب.

Fig. 4. Effects of morphine microinjection into medial septum on anxiety. 

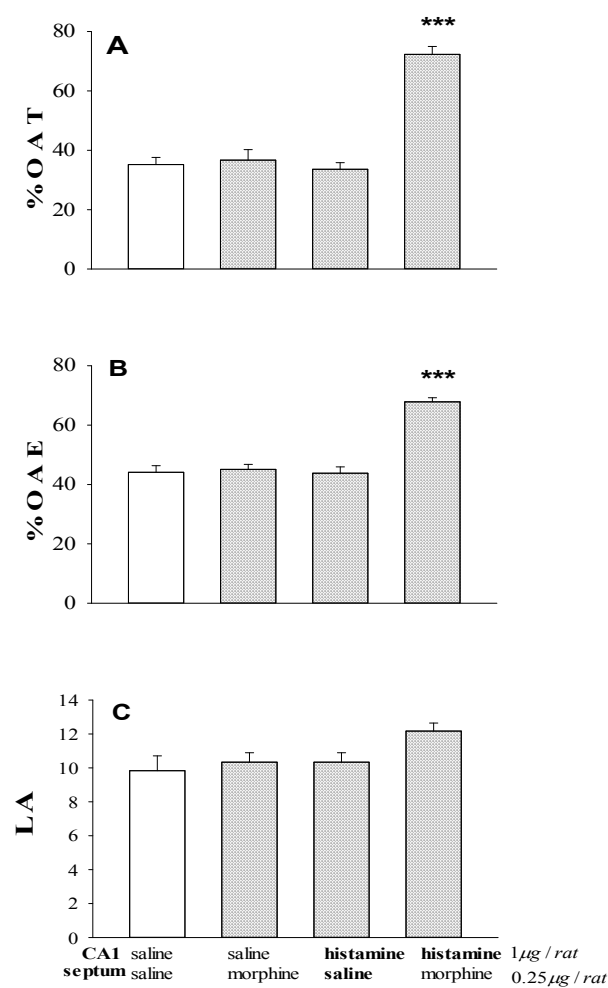

شكل 0- اثر تزريق هيستامين و مورفين بهترتيب به هييو كامب پٍتى و سيتوم ميانى بر رفتار شبهاضطر ابى.

Fig. 5. Effects of histamine and morphine into dorsal hippocampus and medial septum on anxiety.
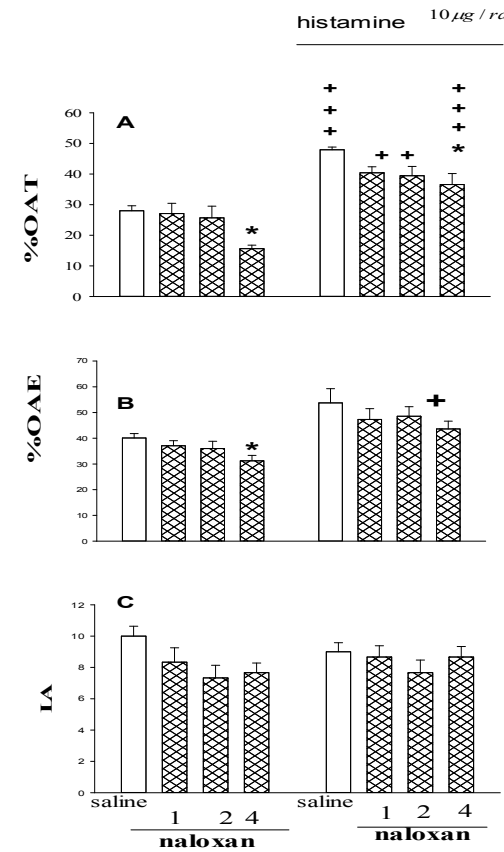

شكل 7 - اثر تزريق هيستامين به هييو كامب يشتى و تزريق نالو كسان به سيتوم ميانى در مقايسه با تزريق نالو كسان به تنهايى به سيتو ميانى بر رفتارهاى شبهاضطر ابى.

Fig. 6. Effects of histamine and noloxone microinjection into dorsal hippocampus and medial septum and - micro injection into medial septum only on noloxone anxiety behavior. 
وهييو كامب شكمى باعث افزايش اضطراب و ترس مىشود

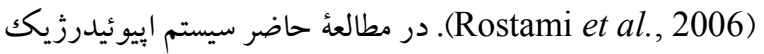
سبتوم ميانى نيز تحت بررسى قرار گرفت. تزريق مورفين

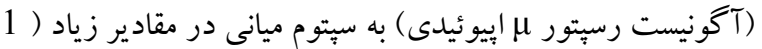
\%OAE و را در آزمون EPM OAT ( $\mu \mathrm{g} / \mathrm{rat}$ بدون اينكه تأثيرى بر فعاليت حركتى حيوانات آزمودنى داشته

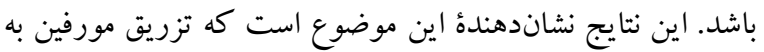
سيتوم ميانى باعث كاهش رفتارهاى شبهاضطرابى شده است. در تأييد نتايج آزمايش حاضر گز ارش باعاى ديخرى نيز حكايت از اين دارند كه مورفين اثر ضد اضطراب خود را پساز تجويز محيطى و

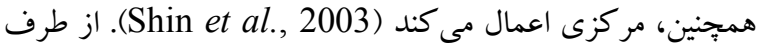
ديخر تجويز نالوكسان،كه يك هُ آنتاكونيست إيوئيدى است، موجب افزايش رفتار اضطرابى در موشهاى صحرايى مىشود

.(Zhang et al., 1996)

تزريق مقدار واحدى از مورفين به داخل صفاق و هستهٔ مركزى آميكدال موجب افزايش معنىدار فعاليت جستجو گرانه موشهاى

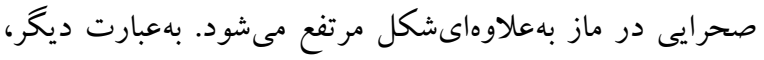

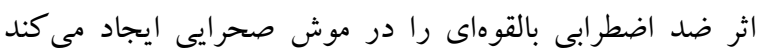

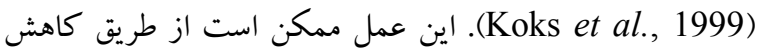
درآزادسازى نور آدرنالين در نواحى متعدد مغزى از جمله هسته

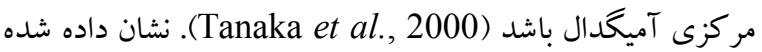

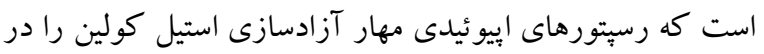

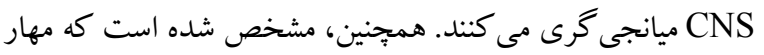

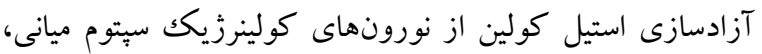

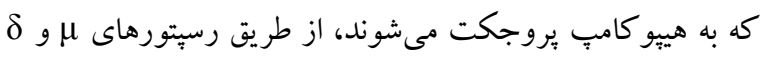
اييوئيدى در سيتوم ميانى ميانجى كرى مى مشود ( Gazyakan et

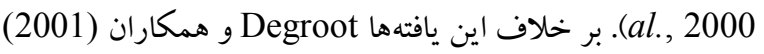

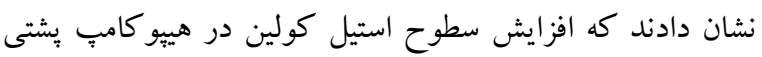

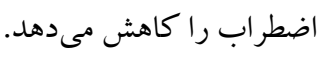
تا اين مرحله از آزمايشهاى حاضر مشخص شدر شد كه سيستم هيستامينرزيك هييو كامب بشتى و و سيستم إيوئيدرزيك إنى سيتوم

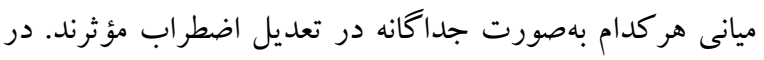

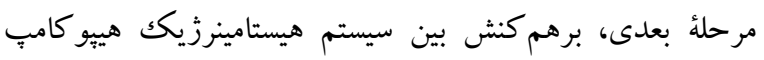

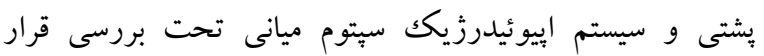

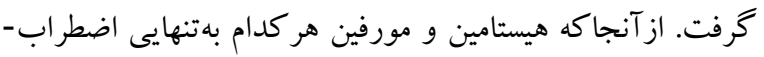

سبتوم ميانى را مهار مى كند: يكك مسير، ورودىهاى مستقيم

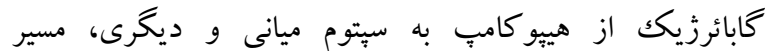
كلو تاماترزيكك به سيتوم جانبى و سبس، مسير كابائرزيكك از سيتوم جانبى به سيتوم ميانى است. سيتوم اصلىترين ورودىهاى كولينرزيك به هيبو كامٍ را فراهم مى كند. همجنين، نورونهاى

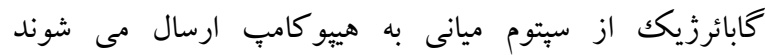
(Mizumori et al., 1999)

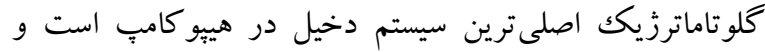
بيشتر نورونهاى موجود در هييو كامٍ كلوتاماتى هستند، اين احتمال وجود داردكه تزريق داروهاى مختلف به داخل هييو-

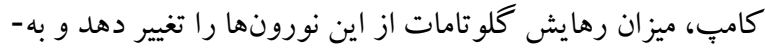

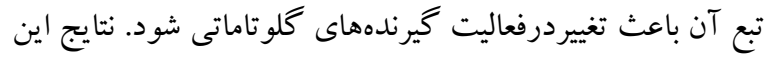
مطالعه نشان مىدهد كه تزريق دوطرفة هيستامين به هييو كامب بشتى بهصورت وابسته به مقدار سبب افزايش OAT\% و OOAE در آزمون EPM بدون هيج گونه اثرى بر فعاليت حر كتى مىشود، كه نشاندهنده اثر اضطرابزدايى آن است. Zarrindast و

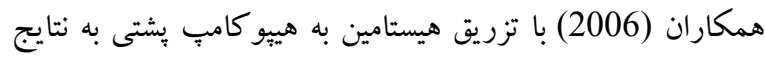

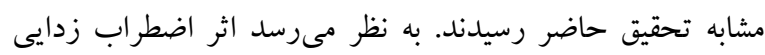

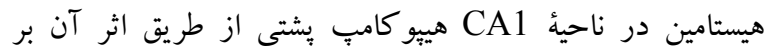
رسيتور هيستامينى H2 است. بهطورى كه در مطالعات قبلى تزريق

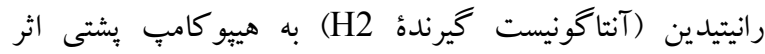

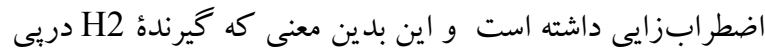

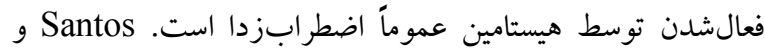

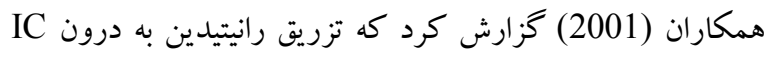

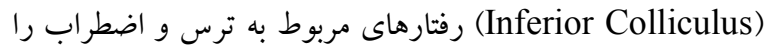

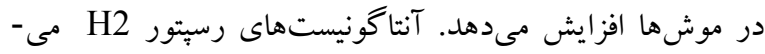
توانند استيل كولين استراز را مهار كنند و بدينترتيب باعث افزايش استيل كولين شوند. ازآنجاكه استيل كولين احتمالاً

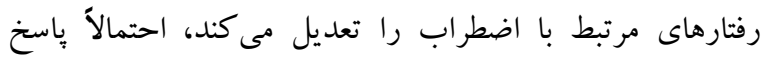
آنتاكونيست هاى هيستامين توسط تغييرات در سطوح استيل كولين

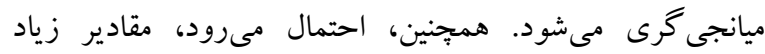

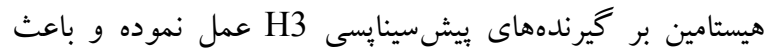
ايجاد باسخهاى اضطرابزدا شود (Zarrindast et al., 2006). بايد توجه داشت كه اثر هيستامين بررفتارهاى شبهاضطرابى شديداً به مكان تزريق وابسته است. براىمثال، تزريق هيستامين به آميكدال 
زيادى نالو كسان در تزريق به سبتوم ميانى، باعث بروز رفتارهاى

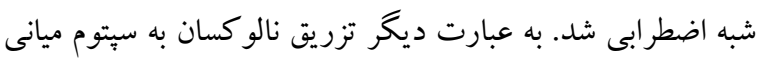

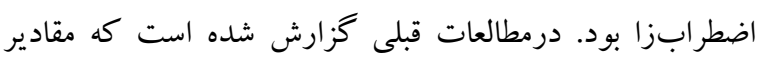

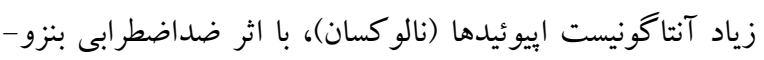
ديازيينها در آزمونهايى كه شاخصهاى ضداضطرابى را نشان مىدهند تداخل دارند. اين امر مىتواند به اين دليل باشدكه

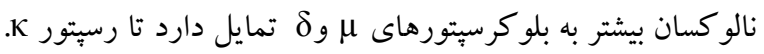

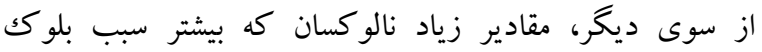

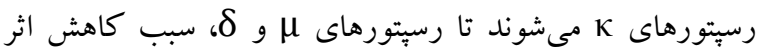
ضداضطراب بنزوديازيينها مىشوند (Tsuda et al., 1996).

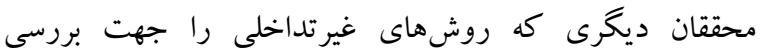
اضطراب به كار بردهاند، مشاهده كردهاند كه مقادير متوسط

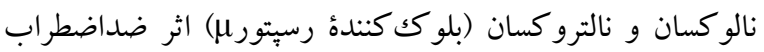

بنزوديازيينها را افزايش مىدهند (Nobre et al., 2000). در اين مطالعه، اثر تزريق مقادير مختلف نالو كسان به سيتوم ميانى

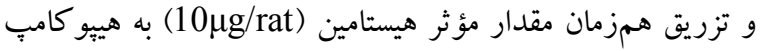

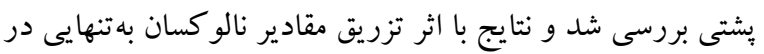

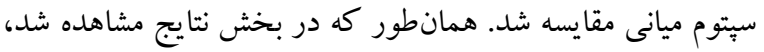

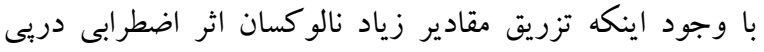
داشت، مقدار مؤثر هيستامين در هييوكامب پشتى اين اثر را

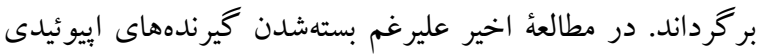
توسط نالو كسان، هيستامين باعث كاهش اضطراب شده است كه

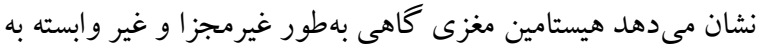
سيستم اييوئيدى مىتواند واكنشهاى اضطرابى را كاهش دهد.

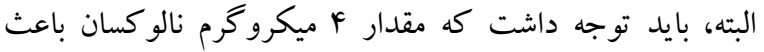
كاهش \%OAT در موشهايى شد كه مقدار مؤثر هيستامين دريافت كرده بودند، اما قدرت اضطرابزدايى هيستامين به مراتب بيشتر از اثر نالو كسان بود. اين يافتهها نشان مىدهند كه در حضور مورفين اثر ضداضطرابى هيستامين تقويت مىشود. همجِنين، در هنخام بلوكهشدن گيرندهاى إييوئيدى توسط نالوكسان، مقدارمؤثر هيستامين مىتو اند اثر ضداضطر ابى را اعمال كند. از اين يافتها مىتوان نتيجه گرفت كه سيستم هيستامينرزيك

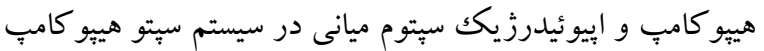
با هم برهم كنش دارند و بر هم كنش اين دو سيستم در تعديل

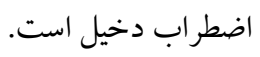

زدا بودند، بهمنظور بررسى برهم كنش اين دو سيستم با هم، مقادير

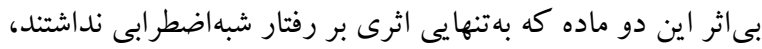
همزمان به هييو كامب پشتى و سيتوم ميانى تزريق شد. بدين منظور،

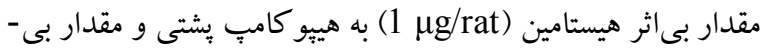

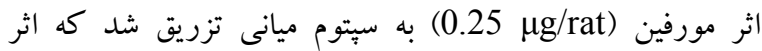

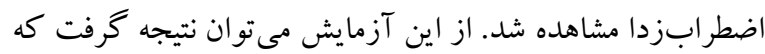
هيستامين و مورفين بهصورت سينرزيستى عمل نموده واضطراب را

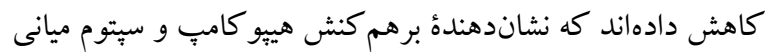
در تعديل رفتارهاى شبهاضطرابى است. مورفين درآزادشدن هيستامين مغزى نقش دارد، زيرا مشخص شده است كه مورفين

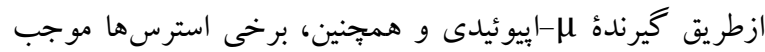
آزادشدن هيستامين مغزى مىشود (Hough et al., 2000). بهعلاوه، مورفين در نورونهاى هيستامينرزيك هستهٔ توبروماميلارى موجب ديلاريزاسيون نورونها و افزايش تحريك يذيرى آنها و آزادشدن هيستامين شده است (Eriksson et al., 2000). بررسىها نشان مىدهند كه ترشح نور آدرنالين به واسطة استرس

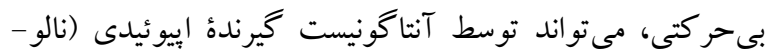
كسان) افزايش يابد، درحالى كه يِيتيدهاى شبهاييوئيدى آزادشده،

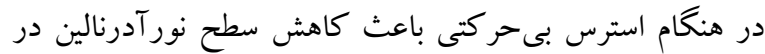
هييوتالاموس، آميكدال وتالاموس مىشود ( Tanaka et al., 1998). مورفين و بعضى يبتيدهاى إييوئيدى، مىتوانند نه تنها ميزان

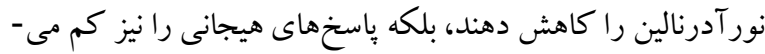

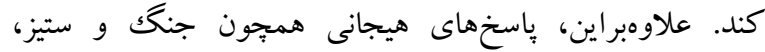

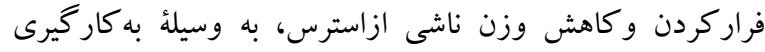
مورفين كاهش مى يابد و اين اثر بهوسيلة نالو كسان از بين مىرود. از طرف ديخر، ميان كنش بين اييوئيدها و نور آدرنالين وجود دارد

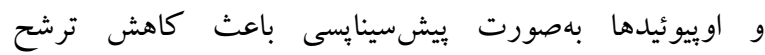
نور آدرنالين مىشوند. دلايلى وجود داردكه اييوئيدها بيان ترس بئس راكاهش مىدهند، بهطورى كه تزريق آكونيست گيرندة ب به به درون آميگدال، باعث كاهش بروز شاخصهاى مربوط به ترس مىشود. مشخص شده است تزريق مورفين به درون آميگدال بيان ترس را كاهش مىدهد. نهايتاً اينكه مورفين آزادسازى هيستامين را ترديا در مغز افزايش مىدهد. در اين مطالعه اثر تزريق نالوكسان (آنتاكونيست رسيتور ب إيوئيدى) به سيتوم ميانى بر رفتارهاى شبهاضطرابى تحت بررسى قرار گرفت. نتايج نشان داد كه مقادير 


\section{REFERENCES}

Bartoletti, M., Gaiardi, M., Gubellini, C., Bacchi, A. and Babbini, M. 1990. Morphine attenuation of a conditioned emotional response in postdependent rats. - Eur. J. Pharmacol. 185: 163-167.

Degroot, A. and Kashluba, S. 2001. Septal GABAergic and hippocampal cholinergic systems modulate anxiety in the plus-maze and shock-probe tests. - Pharmacol. Biochem. Behav. 69: 391-399.

DeVries, A.C., Taymans, S.E., Sundstrom, J.M. and Pert, A. 1998. Conditioned release of corticosterone by contextual stimuli associated with cocaine is mediated by corticotropin-releasing factor. - Brain Res. 786: 39-46.

Drugan, R.C. and Skolnick, P. 1986. Low doses of muscimol produce anticonflict actions in lateral septum of the rat. - Neuropharm. 25: 203-205.

Eriksson, K.S., Stevens, D.R. and Haas, H.L. 2000. Opposite modulation of histaminergic neurons by nociceptin and morphine. - Neuropharm. 39: 2492-2498.

Filliol, D., Ghozland, S., Chluba, J., Martin, M., Matthes, H.W. and Simonin, F. 2000. Mice deficient for delta- and mu-opioid receptors exhibit opposing alterations of emotional responses. - Nat. Genet. 25: 195-200.

Frisch, C., Hasenohrl, R.U., Krauth, J. and Huston, J.P. 1998. Anxiolytic-like behavior after lesion of the tuberomammillary nucleus E2-region. - Exp. Brain Res. 119: 260-264.

Gazyakan, E., Disko, U., Haaf, A., Heimrich, B. and Jackisch, R. 2000. Postnatal development of opioid receptors modulating acetylcholine release in hippocampus and septum of the rat. - Dev. Brain Res. 123: $135-141$

Givens, B.S. and Olten, D.S. 1990. Cholinergic and Gabaergic modulation of medial septal area: effect on working memory. - Behave. Neurosci. 104: 849-855.

Gorden, M.S. 2000. Neurobiology. Third editon. - Oxford University Press. 34- 618 pp.

Hough, L.B., Nalwalk, J.W., Barnes, W.G., Leurs, R., Menge, W.M., Timmerman H. and Wentland, M. 2000. A third life for burimamide. Discovery and characterization of a novel class of non-opioid analgesics derived from histamine antagonists. - Ann. NY Acad. Sci. 909: 25-40.

Kõks, S., Soosaar, A., Võikar, V., Bourin, M. and Vasar, E. 1999. BOC-CCK-4, CCK (B) receptor agonist, antagonizes anxiolytic-like action of morphine in elevated plus-maze. - Neuropeptides 33: 63-69.

Lamour, Y., Bassant, M.H., Jobert, A. and Joly, M. 1989. Septo-hippocampal neurons in the aged rat: relation between their electrophysiological and pharmacological properties and behavioral performances. - Neurobiol. Aging. 10: 181-186.

Mizumori, S.J.Y., Ward, K.E. and Lavoie, A.M. 1992. Medial septal modulation of entorhinal single unit activityin anesthetized and freely moving rat. - Brain Res. 570: 188-197.

Moghaddam, B. 2003. Bringing order to the glutamate chaos in schizophrenia. - Neuron 40: 881-884.

Nobre, M.J., Ribeiro, D.S.N., Aguiar, M.S. and Brandao, M.L. 2000. Blockade of and activation of opioid receptors in the dorsal periaqueductal gray matter produ-

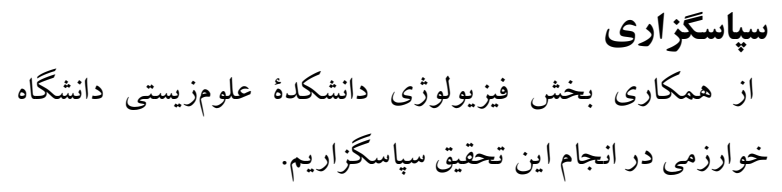


ce defensive behavior in rats in the elevated plus-maze. Eur. J. Pharmacol. 404: 145-151.

Panula, P., Yang, H.P. and Costa, E. 1984. Histaminecontaining neurons in the rat hypothalamus. - Proc. Natl. Acad. Sci. USA. 81: 2572-2576.

Paxinos, G. and Watson, C. 1998. The rat brain in stereotaxic coordinates. - Accademic Press. New York: USA. 28-31 pp.

Pesold, C. and Treit, D. 1994. The septum and amygdala differentially mediate the anxiolytic effects of benzodiazepines. - Brain Res. 638: 295- 301.

Rostami, P., Hajizadeh-Moghaddam, A. and Zarrindast, M.R. 2006. The effects of histaminergic agents in the ventral hippocampus of rats in the plus-maze test of anxiety-like behaviors. - Physiol. Behavior. 87: 891-896.

Santos, N.R., Huston, J.P. and Brandao, M.L. 2003. Blockade of histamine $\mathrm{H} 2$ receptors of the periaqueductal gray and inferior colliculus induces fearlike behaviors. - Pharmacol. Biochem. Behav. 75: 25-33.

Shin, I.C., Kirn, H.C., Swanson, J., Hong, J.T. and Oh, K.W. 2003. Anxio-lyic effects of acute morphine can be modulate by nitric oxide systems. - Pharmacol. 68: 183189.

Swanson L.W. and Cowan W.M. 1979. The connections of the septal region in the rat. - J. Comp. Neurol. 186: 621656.

Tanaka M., Yoshida, M., Emoto, H. and Ishii, H. 2000. Noradrenaline systems in the hypothalamus, amygdala and locus coeruleus are involved in the provocation of anxiety: basic studies. - Eur. J. Pharmacol. 405: 397-406.

Tsuda, M., Suzuki, T., Misawa, M. and Nagase, H. 1996. Involvement of the opioid system in the anxiolytic effect of diazepam in mice. - Eur. J. Pharmacol. 307: 7-14.

Yamatodani, A., Fukuda, H., Wada, H., Iwaeda, T. and Watanabe, T. 1985. High-performance liquid chromatographic determination of plasma and brain histamine without previous purification of biological samples: cation-exchange chromatography coupled with post-column derivatization fluorometry. - J. Chromatogr. 8: 115-23.

Zarrindast, M.R., Torabi, M., Rostami, P. and FazliTabaei, S. 2006. The Effects of histaminergic agents in the dorsal hippocampus of rats in the elevated plus-maze test of anxiety. - Pharmacol. Biochem. Behav. 85: 500506.

Zarrindast, M.R., Valizadegan, F., Rostami, P. and Rezayof, A. 2006. Histaminergic receptors of medial septum and conditioned place preference: D1 dopamine receptor mechanism. - Brain Res. 1109: 108-116.

Zhang, H.T., Xu, Z.M., Luo, Z.P. and Qin, B.Y. 1996. Anxiogenic effect of naltrexone in socialinteraction test in rats. - Zhongguo Yao Li Xue Bao.17: 314-317.

How to cite this article:

Kolivandzadeh, A., Valizadegan, F. and Zarrindast, M.R. 2017. Interaction between dorso-hippocampal histaminergic and medio-septal opioidergic systems in anxiety behavior. Nova Biologica Rep. 4: 189-200.

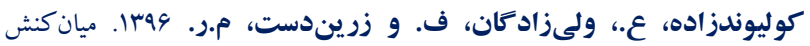

$$
\begin{aligned}
& \text { سيستم هيستامينرزيك هييو كامب پشتى و إيوئيدرزيكك سيتوم ميانى بر رفتارهاى }
\end{aligned}
$$

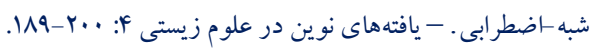

